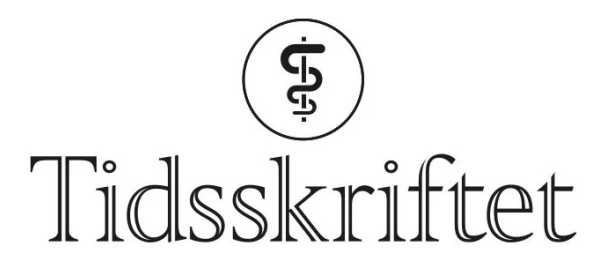

DEN NORSKE LEGEFORENING

\title{
Antitrombotisk behandling ved etablert cerebrovaskulær sykdom
}

\author{
KOMMENTAR \\ HÅKON IHLE-HANSEN \\ haaihl@vestreviken.no \\ Håkon Ihle-Hansen er konstitutert overlege ved Slagavdelingen Bærum Sykehus
}

ELSE CHARLOTTE SANDSET

GURI HAGBERG

HEGE IHLE-HANSEN

Ingen av forfatterne har oppgitt noen interessekonflikter.

Vi takker Pope og medarbeidere for et velskrevet debattinnlegg om intensiv antitrombotisk behandling ved etablert aterosklerotisk sykdom (11). Vi ønsker imidlertid å minne om den økte blødningsrisikoen ved etablert cerebrovaskulær sykdom, og behovet for individualisert behandling hos denne pasientgruppen.

Antitrombotisk behandling ved aterosklerotisk sykdom er i hovedsak indisert ved sekundærforebyggende behandling. Pasientene som er inkludert i COMPASS og PEGASUSTIMI 54-studien har i all hovedsak underliggende coronarsykdom, og i liten grad cerebrovaskulær sykdom. Allikevel ser vi at resultatene i studiene delvis drives av lavere forekomst av cerebrovaskulære hendelser i gruppen som er allokert til intensivert antitrombotisk behandling.

Pasienter med etablert cerebrovaskulær sykdom av aterosklerotisk eller antatt aterosklerotisk etiologi har $ø$ kt risiko for hjerneblødning sammenliknet med personer uten etablert cerebrovaskulær sykdom. PEGASUS-TIMI 54 og COMPASS inkluderte henholdsvis $<1 \%$ og $4 \%$ pasienter med tidligere hjerneslag, og resultatene må av den grunn tolkes med varsomhet hos pasienter med cerebrovaskulær sykdom.

Vi har lite kunnskap om langtidsbehandling med dobbelt platehemmer og kombinasjon av platehemmer og oral antikoagulantia. I de studiene forfatteren refererer til er median oppfølgingstid på henholdsvis 33 (PEGASUS-TIMI 54) og 21-23 (COMPASS) måneder. Residivrisikoen for en ny kardiovaskulær hendelse er størst i den første fasen etter indekshendelse, mens blødningsrisikoen ved aggressiv antitrombotisk behandling øker 
ved langtidsbehandling. Allerede i MATCH studien 2004 fikk vi kunnskap om at dobbel platehemmer over 18 måneder etter et hjerneslag ga økt blødningsrisiko uten sikker forebyggende effekt mot nye cerebrovaskulære hendelser. Nyere studier har vist at initial behandling med dobbel platehemmer ved TIA og mindre slag forebygger tidlig residiv, men at blødningsrisikoen $\emptyset$ ker etter tre måneders behandling (2) $)$. Vi vet også at $\emptyset$ kende alder og skrøpelighet er assosiert med økt blødningsrisiko. Pasientene i PEGASUS-TIMI 54 og COMPASS var langt yngre og sprekere enn en gjennomsnittlig norsk pasient med vaskulær sykdom i hjertet og hjernen $(3,4)$.

Selv om den individuelle risikoen for blødningskomplikasjon er lav, er $>35 \%$ av alle intrakranielle blødninger i Norge assosiert med antitrombotisk behandling (5), og hjerneblødning er assosiert med en mer alvorlig prognose sammenliknet med et hjerneinfarkt (4).

Vi vil derfor anbefale tydelig indikasjonsstilling for valg av antitrombotisk behandling inkludert plan for behandlingslengde.

\section{LITTERATUR}

1. Pope MK, Ghanima W, Atar D. Intensivering av antitrombotisk behandling ved kronisk aterosklerotisk sykdom. Tidsskr Nor Legeforen 2020; 140. doi:10.4045/tidsskr.20.0066. [PubMed] [CrossRef]

2. Prasad K, Siemieniuk R, Hao Q et al. Dual antiplatelet therapy with aspirin and clopidogrel for acute high risk transient ischaemic attack and minor ischaemic stroke: a clinical practice guideline. BMJ 2018;363: k5130. [PubMed][CrossRef]

3. Bønaa KH. Norsk hjerteinfarktregister, Indremedisineren 2017.

4. Årsrapport Norsk hjerneslagregister 2018, https://stolav.no/Documents/Revidert_\%C3\%85rsrapport\%202018_NHR.pdf

5. Gulati S, Solheim O, Carlsen SM et al. Risk of intracranial hemorrhage (RICH) in users of oral antithrombotic drugs: Nationwide pharmacoepidemiological study. PLoS One 2018; 13: e0202575. [PubMed][CrossRef]

Publisert: 7. september 2020. Tidsskr Nor Legeforen. DOI: 10.4045/tidsskr.20.0651

(C) Tidsskrift for Den norske legeforening 2023. Lastet ned fra tidsskriftet.no 26. april 2023. 